\title{
The Study of Water Quality of Several Local Sources
}

\author{
Ábrám Z, Tarcea Monica, Finta Hajnal, Moldovan H, Moldovan Geanina, Nădășan V \\ Department of Hygiene, University of Medicine and Pharmacy, Tîrgu Mureș, Romania
}

Aim: The aim of this study is to analyze the water quality of several local sources from the Toplița-Deda region, as well as from the Gheorgheni basin, in order to inform the population about the water quality and about the importance of the drinking water control.

Method: Repeated water samples were collected from a total number of 41 sources in the two studied regions during 2010. A multiparametric colorimeter, Hanna Instruments C99 was used to determine certain physical and chemical parameters. A number of current and specific microbiological analyses were also carried out.

Results: The average values and the percentage of the positive samples with values above permitted limits were calculated. The highest accepted levels were based on Law no. 458/2002 regarding drinkable water quality. Among the mineral indicators iron exceeded the limit in $18.18 \%$ and water samples were poor in fluoride (83.65\%) and in iodine (98.18\%). A small percentage of sources (3.63\%) indicated pollution, $10.9 \%$ had high nitrate level. Analyzing the microbiological content, our water samples were within the drinkability limits required by law. Conclusion: Our study emphasizes the importance of monitoring water supplies, the awareness of the water quality according to mineral composition, pollution estimation and microbiological characteristics in order to prevent the unexpected influence on the health status of the consumer population.

Keywords: drinking water, water quality, local sources, chemical and microbiological parameters

Received: 12 June 2011

\section{Introduction}

The quality of drinking water is a permanent problem and preoccupation of specialists, because there is a well-known relationship between the composition of water and the consumer's health $[1,2]$.

In spite of the results regarding the central supply of drinking water, there are several rural settlements where the water is supplied by local sources: private and public fountains, wells. In these situations water quality is not controlled permanently, only some temporary analyses are made, thus the risk of water contamination and the appearance of illnesses is increased [3].

The mineral composition and the quality of the water of local sources depend on the quality of the soil and environment, as well as the hygienic conditions $[4,5]$.

It is true that the control of the water center is more important, because it supplies a much higher number of consumers with drinking water than local sources, which supply water for a smaller number of persons. However, monitoring the quality of local sources - especially public sources - is also important, because if the wells are polluted, they can cause hidric epidemies and illnesses or methemoglobinaemia [6,7].

Our institution has already carried out several studies regarding the quality of surface water, underground water and drinking water $[8,9,10]$. We consider that in this way we can contribute to the better knowledge about water quality of local sources and we can inform the consumers about it.

Correspondence to: Zoltán Ábrám

E-mail: abramzoltan@yahoo.com
The aim of this study is to analyze the water quality of several local sources in order to inform the population about the water quality and about the importance of the drinking water control [11].

\section{Methodology}

The local sources studied originated in the Deda-Toplița region (Deda, Răstolița, Lunca Bradului, Stânceni), and the Gheorgheni basin (Ditrău, Lăzarea, Remetea, Suseni, Chilieni, Jolotca). Water samples from sources used in rural schools and train stations, public fountains, public wells, wells of turist interest were analyzed.

In the two regions studied during the year 2010, water samples were collected from 41 water sources, $2-3$ samples from each source. A multiparametric colorimeter, Hanna Instruments C99 was used to determine the following physical and chemical parameters: temperature, $\mathrm{pH}$, hardness, chloride, iron, fluoride, iodine (mineral compounds), ammonium, nitrites (indicators of pollution), dissolved oxygen, nitrates (toxic compound). In the microbiological laboratory the total number of germs, Escherichia Coli, Salmonella and Shigella were studied.

After the water collection, the samples were stored in a refrigerator for a few days. The chemical analyses were carried out in the laboratory of the Departement of Hygiene, and the microbiological determinations at the Departement of Microbiology of the University of Medicine and Pharmacy of Tîrgu Mureş. The samples for the microbiological analysis were collected in sterile conditions.

The highest accepted levels were based on Law no. 458/2002 regarding drinkable water quality [12]. 
Table I. Comparison of the average values of the regions studied

\begin{tabular}{lccc}
\hline & $\begin{array}{c}\text { Deda- } \\
\text { Toplița }\end{array}$ & Gheorgheni & $\begin{array}{c}\text { Values of } \\
\text { limits }\end{array}$ \\
\hline Temperature $\left({ }^{\circ} \mathrm{C}\right)$ & 12.56 & 10.91 & - \\
$\mathrm{pH}($ units) & 7.15 & 6.8 & $6.5-9.5$ \\
Hardness $($ German grade) & 5.46 & 14.24 & $>5$ \\
Chloride $(\mathrm{mg} / \mathrm{l})$ & 25.85 & 64.05 & 250 \\
Iron $(\mu \mathrm{g} / \mathrm{l})$ & 120 & 325 & 200 \\
Fluoride $(\mathrm{mg} / \mathrm{l})$ & 0.245 & 0.355 & $0.5-1.2$ \\
lodine $(\mu \mathrm{g} / \mathrm{l})$ & 0.45 & 0.35 & $>5$ \\
Ammonium $(\mathrm{mg} / \mathrm{l})$ & 0.075 & 0.165 & 0.50 \\
Nitrite $(\mathrm{mg} / \mathrm{l})$ & 0 & 0 & 0.50 \\
Nitrate $(\mathrm{mg} / \mathrm{l})$ & 12.00 & 28.86 & 50 \\
Dissolved oxygen $(\mathrm{mg} / \mathrm{l})$ & 8.10 & 7.17 & $>5$ \\
\hline
\end{tabular}

\section{Results}

The average values and the percentage of the positive samples were calculated, in comparison between the two regions studied. The water quality of some public wells situated near the roads was carefully analyzed. Sixty-one tests were carried out in the Deda-Topliţa region and 56 in the Gheorgheni basin. The data were analysed using SPSS computer software. In statistical calculations the chi square test was applied with a $95 \%$ confidence interval $(95 \% \mathrm{CI})$.

Table I shows the comparison of the average values of the studied regions. The hardness of water samples from the Gheorgheni basin was nearly three times higher (14.24 German grade) than in the Deda-Toplița region. The chloride, iron and fluoride content of these samples was significantly higher as well, $\mathrm{p}<0.05$. The average iodine content was very low in both cases. The nitrate level was also much higher in the samples collected from the lower situated areas of the Gheorgheni basin, than in the mountainous villages of the Deda-Topliţa region $(28.86 \mathrm{mg} / \mathrm{l})$.

Analyzing the percentage of the positive samples, with values above the accepted limits, it is noticed that the hardness of over $25 \%$ of samples exceeded 10 German grades, while among the mineral indicators iron exceeded the limit in $18.18 \%$ and water samples were poor in fluoride $(83.65 \%)$ and in iodine $(98.18 \%)$.

A small percentage of sources $(3.63 \%)$ indicated pollution, $10.9 \%$ had high nitrate levels, the positive results

Table III. The chemical water quality of some public wells

\begin{tabular}{lcccc}
\hline & Sălard & Meștera & Borzont & Bucin \\
\hline Temperature $\left({ }^{\circ} \mathrm{C}\right)$ & 13 & 11 & 10 & 10 \\
$\mathrm{pH}$ (units) & 7.5 & 7.6 & 6.9 & 7.9 \\
Hardness (german grade) & 5.6 & 7.25 & 5.61 & 5.48 \\
Chloride $(\mathrm{mg} / \mathrm{l})$ & 21.42 & 10.58 & 17.73 & 3.84 \\
Iron $(\mu \mathrm{g} / \mathrm{l})$ & 0.05 & 0.15 & 0.02 & 0.01 \\
Fluoride $(\mathrm{mg} / \mathrm{l})$ & 0.19 & 0.21 & 0.07 & 0.14 \\
lodine $(\mu \mathrm{g} / \mathrm{l})$ & 0.55 & 0.5 & 0.5 & 0.7 \\
Ammonium $(\mathrm{mg} / \mathrm{l})$ & 0.09 & 0.05 & 0.22 & 0.11 \\
Nitrite $(\mathrm{mg} / \mathrm{l})$ & 0 & 0 & 0 & 0 \\
Nitrate $(\mathrm{mg} / \mathrm{l})$ & 6.66 & 5.97 & 2.32 & 6.2 \\
Dissolved oxygen $(\mathrm{mg} / \mathrm{l})$ & 10.7 & 8.7 & 10.7 & 7.2 \\
\hline
\end{tabular}

Table II. The percentage of the positive samples (\%)

\begin{tabular}{lccc}
\hline & $\begin{array}{c}\text { Deda- } \\
\text { Toplița }\end{array}$ & Gheorgheni & Total \\
\hline $\mathrm{pH}$ & 0 & 0 & 0 \\
Hardness & 48.2 & 16 & 32.7 \\
Chloride & 0 & 0 & 0 \\
Iron & 13.7 & 23 & 18.18 \\
Fluoride & 96.55 & 69.23 & 83.65 \\
lodine & 100 & 96.15 & 98.18 \\
Ammonium & 0 & 7.69 & 3.63 \\
Nitrite & 0 & 0 & 0 \\
Nitrate & 0 & 23 & 10.9 \\
Dissolved oxygen & 0 & 0 & 0 \\
Dissolved oxygen (mg/l) & 8.10 & 7.17 & $>5$ \\
\hline
\end{tabular}

being determined only in the Gheorgheni basin. The increased levels of nitrate are determined by the composition of soil, but the higher ammonium levels, above the maximum accepted values, show the existence of a source of water pollution.

Analyzing the microbiological content, our water samples were within the drinkability limits required by law. The total number of germs per $\mathrm{ml}$ complied with the expectations of STAS 1342/91, while no Escherichia Coli, Salmonella or Shigella were detected in the microbiologically analyzed water samples.

Table III shows the average data regarding the chemical water quality of some public wells, situated near the main roads of the two studied regions, this water being preferred not only by the local population, but by the tourists and the drivers as well. The complex chemical analysis of the four most important public wells (Sălard, Meștera, Borzont, Bucin) shows that the water quality is good, without any signs of water pollution. They are rich in oxygen and quite poor in mineral compounds, having a low hardness and a small content of nitrate, characteristic for mountainous area. No significant differences were found in the composition of the analyzed samples.

\section{Discussion}

We consider that it is important to monitor water supplies, as a preventive method, to be aware of the water quality regarding mineral composition, pollution estimation and microbiological characteristics, in order to prevent the unexpected consequences on the health of the consumer population $[13,14]$.

The results and the conclusions of this research were communicated to the local authorities who were asked to inform the population about the water quality and to make the necessary investments and disinfection if the samples were positive. Because in both regions the concentrations of fluoride and iodine is low, this fact can be considered a risk with impact on the dental resistance structure and on the thyroid activity of the consumers.

Continous collaboration with the local council is recommended, in order to control the quality of drinking 
water and to inform the population about it. If necessary, the rehabilitation and the disinfection of the local sources of improper quality is recommended.

\section{Conclusions}

The local sources analyzed from Gheorgheni basin have a much higher hardness and are richer in mineral compounds than the samples from the Deda-Toplița region. In both regions the concentrations of fluoride and iodine is low.

A small percentage of sources indicated pollution, one in ten samples had a high nitrate level. The average values were higher in the Gheorgheni region.

The water of public wells situated near the roads corresponds to the conditions characteristic for drinking water.

\section{References}

1. Ionuț C, Popa M. Compendiu de Igienă, Editura Medicală Universitară "Iuliu Hațieganu”, Cluj-Napoca, 2004.

2. Mănescu S. Igiena, Editura Medicală, București, 1996.

3. György É, Máthé I, Lőrinczi L, et al. Gyergyóújfalui kútvizek és ásványvizek mikrobiológiai vizsgálata. Orvostudományi Értesítő. 2007;80:67-69.
4. Ábrám Z, Tarcea M, Finta H, Moldovan H. Îndrumar practic de sănătatea mediului, Editura University Press, Tg. Mures, 2007.

5. Johnson DL, Ambrose SH, Bassett TJ, et al. Meanings of environmental terms. Journal of Environmental Quality. 1997;26:581-589.

6. Ureche R, Ábrám Z, Domahidi I. Igiena mediului ambiant, U.M.F. TârguMureș, curs litografiat, 1995.

7. Gibbons J, Laha S. Water purification systems: A comparative analysis based on the occurrence of disinfection by products. Environmental Pollution. 2009;106:425-428.

8. Ábrám Z, Fărcaș O, Șolea A, Gyarfas E, Milos I. Calitatea unor surse locale de apă situate pe ruta Toplița-Deda. Revista de Medicină și Farmacie. 1997;43(SIII):39-40.

9. Tarcea M, Ureche R, Ábrám Z, et al. Conținutul mineral și organic al apei de fântână din diverse zone ale țării. Revista de Igienă si Sănătate Publică. 2008;58:142-149.

10. Ureche R, Ábrám Z, Orbán A. Cercetarea unor indicatori de potabilitate ai apei freatice în Târgu-Mureș, Revista de Medicină și Farmacie. 1998;44:162-164.

11. ${ }^{\star \star \star}$ World Health Organisation, Geneve. Guidelines for Drinking Water Quality, vol. II, 1997.

12. ${ }^{\star \star \star}$ Legea nr. 458 din 8 iulie 2002, partea I, privind calitatea apei potabile, din Monitorul oficial nr. 552 din 29 iulie 2002.

13. ${ }^{\star \star \star}$ International Organization for Standardization - Water quality, 2008

14. Burton GA, Pitt R. Stormwater Effects Handbook: A Toolbox for Watershed Managers, Scientists, and Engineers. CRC/Lewis Publishers, New York, 2001. 